\title{
Downregulation of Vascular Endothelial Growth Factor Receptors by Tumor Necrosis Factor- $\alpha$ in Cultured Human Vascular Endothelial Cells
}

\author{
Cam Patterson, ${ }^{\star}$ Mark A. Perrella, ${ }^{\star \star \S}$ Wilson O. Endege, ${ }^{\star}$ Masao Yoshizumi, ${ }^{\star \ddagger}$ Mu-En Lee, ${ }^{* \neq \|}$ and Edgar Haber ${ }^{\star \ddagger}$ \\ *Cardiovascular Biology Laboratory, Harvard School of Public Health, ${ }^{\ddagger}$ Department of Medicine, Harvard Medical School, and \\ ${ }^{\S}$ Pulmonary and $\|^{\|}$Cardiovascular Divisions, Brigham and Women's Hospital, Boston, Massachusetts 02115
}

\begin{abstract}
Vascular endothelial growth factor (VEGF) potently stimulates angiogenesis, whereas TNF- $\alpha$ has both pro- and antiangiogenic activity. By measuring thymidine uptake, we found that TNF- $\alpha$ blocked a 2.3-fold increase in DNA synthesis induced by VEGF in human endothelial cells. To explore the possibility that the two interact to regulate endothelial cell proliferation, we examined the effect of TNF- $\alpha$ on VEGF receptor expression. In venous and arterial endothelial cells, TNF- $\alpha$ potently reduced mRNA transcripts of the two VEGF receptors (KDR/flk-1 and flt-1) in a doseand time-dependent fashion. TNF- $\alpha$ at $1 \mathrm{ng} / \mathrm{ml}$ induced maximal inhibition of mRNA expression, which fell by $\sim 70 \%$ after $24 \mathrm{~h}$. TNF- $\alpha$ treatment did not significantly affect the KDR/flk-1 half-life but did decrease its rate of transcription to $40 \%$ of control. The decrease in KDR/flk-1 mRNA depended partially on new protein synthesis and was abolished by phorbol ester pretreatment. TNF- $\alpha$ decreased the amount of ${ }^{35}$ S-labeled KDR/flk-1 immunoprecipitated by an antibody specific for KDR/flk-1 to $18 \%$ of control. We conclude that TNF- $\alpha$ downregulates expression of both VEGF receptors in human endothelial cells and that this effect is transcriptional (at least for KDR/flk-1). These data support the hypothesis that TNF- $\alpha$ exerts its antiangiogenic effect in part by modulating the VEGF-specific angiogenic pathway. (J. Clin. Invest. 1996. 98:490-496.) Key words: angiogenesis • gene regulation $\bullet$ cytokines $\cdot$ phorbol ester $\bullet$ proliferation
\end{abstract}

\section{Introduction}

Angiogenesis, the growth of new blood vessels from existing vessels, is essential for normal development and physiologic processes such as bone remodeling and the menstrual cycle; moreover, it is a critical component of a variety of common disease processes including tumor growth and metastasis, vascular disease, ocular neovascularization, and inflammatory arthritis (1). Inhibition of angiogenesis in vivo blocks tumor growth (2) and arrests progression of retinopathy (3) in exper-

Address correspondence to Dr. Edgar Haber, Cardiovascular Biology Laboratory, Harvard School of Public Health, 677 Huntington Avenue, Boston, MA 02115. Phone: 617-432-1010; FAX: 617-4324098; E-mail: haber@cvlab.harvard.edu.

Received for publication 16 February 1996 and accepted in revised form 25 April 1996.

J. Clin. Invest.

(C) The American Society for Clinical Investigation, Inc.

0021-9738/96/07/0490/07 \$2.00

Volume 98, Number 2, July 1996, 490-496 imental models. Conversely, therapeutic enhancement of angiogenesis has been proposed as a treatment for peripheral vascular disease (4).

A number of growth factors and cytokines regulate angiogenesis positively or negatively (5). Among these, only vascular endothelial growth factor (VEGF) ${ }^{1}$ has a pattern of expression that would suggest a specific angiogenic function in normal development $(6)$. VEGF is a potent mitogen $(7,8)$ that promotes the growth and maintenance of vascular endothelial cells and the development of new blood vessels through interactions with its endothelial cell-specific receptors KDR/flk-1 and flt-1 (9-11). Moreover, the spatial and temporal expression of VEGF during embryogenesis implies a critical role for VEGF in the differentiation of endothelial cells from hemangioblasts during the earliest stages of vascular development $(12,13)$.

In contrast, TNF- $\alpha$, an inflammation- and neoplasia-associated cytokine that alters expression of many genes (14), can promote or inhibit endothelial cell growth and angiogenesis depending on the system under study $(5,15)$. In the rabbit cornea (16) and in the chick chorioallantoic membrane (17), TNF- $\alpha$ induces new vessel growth, possibly by stimulating stromal or inflammatory cells to release angiogenic mediators. TNF- $\alpha$ itself stimulates chemotaxis in bovine capillary endothelial cells (17) and induces autophosphorylation of the receptor tyrosine kinase Eck, a likely mediator of angiogenic signaling, in human endothelial cells (18). In contrast, TNF- $\alpha$ impairs endothelial cell growth in vitro (19) and tumor cell mediated angiogenesis (20). Endothelial cell growth induced by basic fibroblast growth factor is markedly inhibited by TNF- $\alpha$ (16), as is endothelial monolayer integrity (21). The varied effects of TNF- $\alpha$ on endothelial cells and new vessel growth suggest the presence of more than one angiogenic signaling pathway and that TNF- $\alpha$, in contrast with VEGF, may have different actions on endothelial cells depending on the biological context (15).

Because TNF- $\alpha$ has varied and contrasting effects on angiogenesis, we explored the possibility that TNF- $\alpha$ interacts directly with the well-defined and specific VEGF system. We demonstrate that TNF- $\alpha$ potently inhibits VEGF-induced endothelial cell proliferation and that this inhibition is accompanied by downregulation of the mRNAs for KDR/flk-1 and flt-1, the two endothelial cell-specific receptors for VEGF. We also show for KDR/flk-1 that this downregulation is transcription-

1. Abbreviations used in this paper: HAEC, human aortic endothelial cell(s); HB-EGF, heparin-binding epidermal growth factor-like growth factor; HUVEC, human umbilical vein endothelial cell(s); PDTC, pyrrolidine dithiocarbamate; TPA, 12-O-tetradecanoylphorbol-13-acetate; VEGF, vascular endothelial growth factor. 
ally mediated and is accompanied by a decrease in immunoprecipitable KDR/flk-1 protein.

\section{Methods}

Cell culture and $m R N A$ isolation. Primary culture human umbilical vein endothelial cells (HUVEC) and human aortic endothelial cells (HAEC) were obtained from Clonetics Corp. (San Diego, CA) and were grown in M199 medium supplemented with 20\% FCS (HyClone, Logan, UT), $30 \mathrm{mg}$ endothelial cell growth supplement (Collaborative Biomedical, Bedford, MA), $25 \mathrm{mg}$ heparin, $100 \mathrm{U}$ of penicillin $/ \mathrm{ml}$, and $100 \mu \mathrm{g}$ of streptomycin $/ \mathrm{ml}$ in gelatin-coated tissue culture plates. Bovine aortic endothelial cells were isolated and cultured in DME (JRH Biosciences, Lenexa, KS) supplemented with $10 \%$ FCS. Primary culture cells were passaged every $4-6 \mathrm{~d}$ and experiments were performed on cells three to six passages from primary culture. After the cells had grown to confluence, they were placed in quiescence medium (M199 medium supplemented with 5\% FCS without endothelial cell growth supplement). Total RNA from cells in culture was prepared by guanidinium isothiocyanate extraction and centrifugation through cesium chloride (22). Recombinant human TNF- $\alpha$ was obtained from Genzyme (Cambridge, MA), pyrrolidine dithiocarbamate (PDTC), dexamethasone, indomethacin, and 12- $O$-tetradecanoylphorbol-13-acetate (TPA) from Sigma Chemical Co. (St. Louis, MO), dibutyryl-cyclic AMP from Calbiochem-Behring Corp. (San Diego, CA), and recombinant human VEGF from Collaborative Biomedical. Recombinant human TGF- $\beta 1$ was provided by Bristol-Myers Squibb (Seattle, WA).

Northern analysis. RNA blots were hybridized as described (23). Total RNA $(10 \mu \mathrm{g})$ from cells in culture was fractionated on a $1.3 \%$ formaldehyde-agarose gel and transferred to nitrocellulose filters. cDNA probes were labeled with ${ }^{32} \mathrm{P}$ by random priming and used to hybridize filters. Filters were then washed and autoradiographed for $4-8 \mathrm{~h}$ on Kodak XAR film at $-80^{\circ} \mathrm{C}$. Filters were stripped of radioactive probe in a $50 \%$ formamide solution at $80^{\circ} \mathrm{C}$ and rehybridized with an end-labeled $18 \mathrm{~S}$ ribosomal RNA oligonucleotide to correct for loading (24). Filters were scanned and radioactivity was measured on a PhosphorImager running the ImageQuant software (Molecular Dynamics, Sunnyvale, CA). To correct for differences in RNA loading, the signal intensity for each RNA sample hybridized to cDNA probes was divided by that for each sample hybridized to the $18 \mathrm{~S}$ ribosomal probe. For RNA studies, experiments were repeated at least three times. Representative experiments are shown unless statistical analysis was necessary, in which case data from multiple experiments were pooled and expressed as the mean \pm SEM.

Plasmids. A 567-bp human KDR/flk-1 cDNA fragment was generated from HUVEC total RNA by the reverse-transcriptase PCR (22) as described (25). The human flt-1 cDNA clone was generously provided by Dr. Timothy Quinn (University of California, San Francisco, CA).

Nuclear run-on analysis. Confluent HUVEC were treated with vehicle (control) or TNF- $\alpha(1 \mathrm{ng} / \mathrm{ml})$ for $18 \mathrm{~h}$. The cells were then lysed and the nuclei were isolated as described by Perrella et al. (26). Nuclear suspension $(200 \mu \mathrm{l})$ was incubated with $0.5 \mathrm{mM}$ each of CTP, ATP, and GTP and with $250 \mu \mathrm{Ci}$ of ${ }^{32} \mathrm{P}$-labeled UTP $(3,000 \mathrm{Ci} / \mathrm{mmol}$; DuPont/NEN, Boston, MA). The samples were extracted with phenol/chloroform, precipitated, and resuspended at equal counts/min/ $\mathrm{ml}$ in hybridization buffer $\left(15 \times 10^{6}\right.$ counts $\left./ \mathrm{min} / \mathrm{ml}\right)$. Denatured probes $(1 \mu \mathrm{g})$ dot blotted onto nitrocellulose filters were hybridized at $40^{\circ} \mathrm{C}$ for $4 \mathrm{~d}$ in the presence of formamide. cDNAs for the $K D R /$ $f l k-1$ and $\beta$-actin genes were used as probes. The filters were scanned and radioactivity was measured on a PhosphorImager running the ImageQuant software. The amount of sample hybridizing to the $\mathrm{KDR} / \mathrm{flk}-1$ probe was divided by that hybridizing to the $\beta$-actin probe, and the corrected density was reported as the percentage change from control.

Immunoprecipitation. HUVEC in confluent monolayers were made quiescent and treated with TNF- $\alpha(1 \mathrm{ng} / \mathrm{ml})$ or vehicle for $24 \mathrm{~h}$.
The cells were incubated with $\left[{ }^{35} \mathrm{~S}\right]$ methionine $(100 \mu \mathrm{Ci} / \mathrm{ml}$; DuPont/ $\mathrm{NEN}$ ) for $2 \mathrm{~h}$ and lysed in RIPA buffer at $4^{\circ} \mathrm{C}$ for $10 \mathrm{~min}$. After sedimentation of the insoluble fraction, the protein extract was cleared with protein A Sepharose $(0.1 \mu \mathrm{g} / \mu \mathrm{l}$; Pharmacia Biotech, Piscataway, $\mathrm{NJ})$ for $1 \mathrm{~h}$ at $4^{\circ} \mathrm{C}$ followed by centrifugation and collection of the supernatant. Protein concentrations in the whole cell lysates were determined by a modified Lowry procedure (DC protein assay; BioRad, Melville, NY) and were confirmed by SDS-polyacrylamide gel fractionation of samples, followed by Coomassie blue staining.

Protein samples $(500 \mu \mathrm{g})$ were diluted to $1 \mu \mathrm{g} / \mu \mathrm{l}$ with immunoprecipitation buffer (50 mM Tris-Cl, $\mathrm{pH} 8.0,150 \mathrm{mM} \mathrm{NaCl}, 0.1 \%$ SDS, $1 \%$ Nonidet P-40, $0.5 \%$ sodium deoxycholate, 2 mM EDTA, 0.5 $\mathrm{mM}$ dithiothreitol, $0.02 \%$ sodium azide) plus $4 \mathrm{mg} / \mathrm{ml}$ BSA and rocked gently at $4^{\circ} \mathrm{C}$ for $1 \mathrm{~h}$. Specific antibody was added to a concentration of $50 \mathrm{ng} / \mu \mathrm{l}$ and the sample was rocked at $4^{\circ} \mathrm{C}$ for $1.5 \mathrm{~h}$. Protein A Sepharose $(10 \mu \mathrm{g})$ was then added and rocking was allowed to continue for another $1.5 \mathrm{~h}$. The antigen-antibody-protein A Sepharose conjugates were removed by centrifugation and washed four times with immunoprecipitation buffer. The conjugates were denatured at $100^{\circ} \mathrm{C}$ for $5 \mathrm{~min}$ in Laemmli buffer and size-fractionated on a $7 \%$ SDS-polyacrylamide gel, which was then vacuum dried and autoradiographed. Autoradiograms were scanned (Scanmaster 3+; Howtek, Hudson, NH) into Adobe Photoshop 3.0, and Scion Image 1.55 was used to quantitate immunoprecipitated protein.

$\left[{ }^{3} H\right]$ Thymidine incorporation. HUVEC grown to near confluence in gelatin-coated 24-well tissue culture plates were made quiescent and treated with vehicle or TNF- $\alpha(1 \mathrm{ng} / \mathrm{ml})$ for $12 \mathrm{~h}$ before addition of VEGF $(10 \mathrm{ng} / \mathrm{ml})$ or vehicle. Cells were treated with VEGF for $24 \mathrm{~h}$ and labeled with $\left[\right.$ methyl $\left.-{ }^{3} \mathrm{H}\right]$ thymidine (DuPont/NEN) at 1 $\mu \mathrm{Ci} / \mathrm{ml}$ during the last $3 \mathrm{~h}$ of VEGF treatment. After labeling, the cells were washed with PBS and fixed in cold $10 \%$ TCA, and then washed with $95 \%$ ethanol. Incorporated $\left[{ }^{3} \mathrm{H}\right]$ thymidine was extracted in $0.2 \mathrm{M} \mathrm{NaOH}$ and measured in a liquid scintillation counter. Values were expressed as the mean \pm SEM from six wells from two separate experiments.

Statistical analysis. When appropriate, data from image analyses and $\left[{ }^{3} \mathrm{H}\right]$ thymidine incorporation were expressed as the mean \pm SEM. Simple linear regression analysis was performed on data from mRNA half-life studies by the least squares method. For multiple treatment groups, a factorial ANOVA followed by Fisher's least significant difference test was applied. Statistical significance was accepted at $P<0.05$.

\section{Results}

Effect of TNF- $\alpha$ on VEGF-induced endothelial cell proliferation. TNF- $\alpha$ blunts the mitogenic action of acidic and basic fibroblast growth factors on bovine aortic endothelial cells in a concentration-dependent manner (16). To determine whether TNF- $\alpha$ also blocks the proliferative effect of VEGF on human endothelial cells, we measured $\left[{ }^{3} \mathrm{H}\right]$ thymidine incorporation as a marker of DNA synthesis after stimulating HUVEC with human recombinant VEGF. In quiescent HUVEC, pretreatment with $\mathrm{TNF}-\alpha$ alone $(1 \mathrm{ng} / \mathrm{ml})$ at a concentration similar to that tested by Frater-Schroder et al. (16) decreased $\left[{ }^{3} \mathrm{H}\right]$ thymidine incorporation only slightly in comparison with HUVEC pretreated with vehicle (Fig. 1). (At $1 \mathrm{ng} / \mathrm{ml}, \mathrm{TNF}_{-} \alpha$ has a minimal cytotoxic effect on endothelial cells in culture [16, 17].) VEGF treatment alone $(10 \mathrm{ng} / \mathrm{ml})$ enhanced $\left[{ }^{3} \mathrm{H}\right]$ thymidine incorporation in HUVEC by 2.3 -fold in comparison with control cells, as has been demonstrated in endothelial cells of bovine origin (8). However, pretreatment of HUVEC with TNF- $\alpha$ totally abolished the effect of VEGF on DNA synthesis. These results demonstrate that $\mathrm{TNF}-\alpha$ blocked the proliferative response of HUVEC to VEGF, as it does for fibroblast growth factors. Because little is known about the regulation of VEGF receptor 


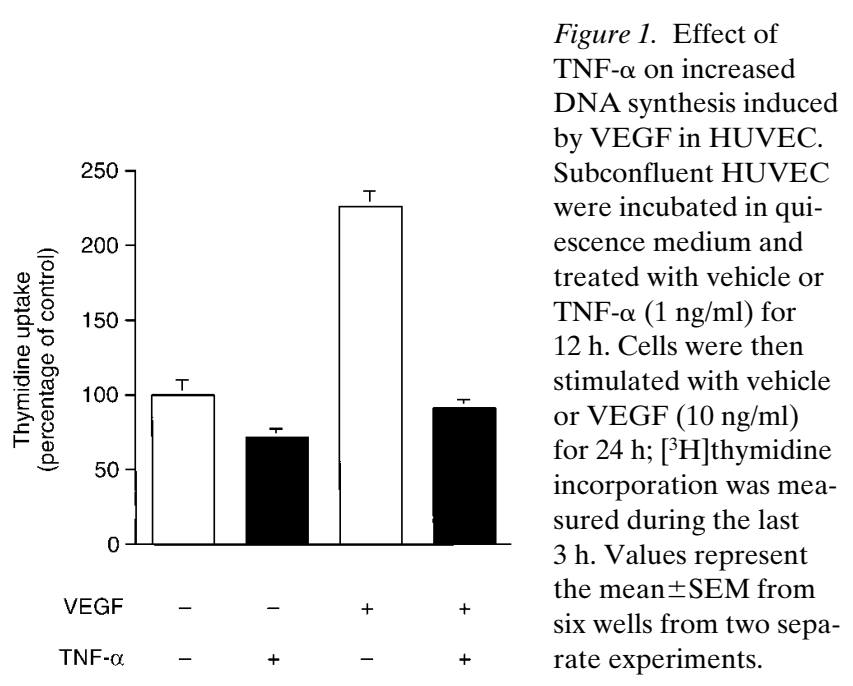

expression in endothelial cells, we next examined whether this alteration in VEGF signaling by TNF- $\alpha$ was due at least in part to regulation by TNF- $\alpha$ of KDR/flk- 1 and flt-1.

$T N F-\alpha$ downregulates $V E G F$ receptor $m R N A s$. We have shown that the 5.7-kb KDR/flk-1 mRNA is expressed constitutively in HUVEC (25). Here we demonstrate that the 7.0-kb flt- 1 mRNA is also abundantly expressed by HUVEC in culture. Treatment of HUVEC with TNF- $\alpha(10 \mathrm{ng} / \mathrm{ml})$ resulted in a decrease in the message for both receptors that was evident by $6 \mathrm{~h}$. Messenger RNA levels reached 28 and $33 \%$ of 0 -h values, respectively, for KDR/flk- 1 and flt- 1 after $24 \mathrm{~h}$ of treatment (Fig. $2 A$ ). That this effect was due to TNF- $\alpha$ alone and not to the state of quiescence was demonstrated by including a control sample which had been made quiescent for $24 \mathrm{~h}$ and treated with vehicle alone; quiescence did not decrease the KDR/flk-1 or flt-1 message. To exclude the possibility that downregulation of the two receptors was due to a generalized decrease in mRNA production induced by TNF- $\alpha$, we hybridized the same blots to a human heparin-binding EGF-like growth factor (HB-EGF) probe. Under these conditions, TNF- $\alpha$ induced a biphasic increase in HB-EGF message (data not shown), consistent with the results of our previous experiments (24). To demonstrate that the effect of TNF- $\alpha$ was not specific to endothelial cells of venous origin, we then performed identical experiments in HAEC (Fig. 2 B). A similar, potent decrease in the message for both receptors was seen in HAEC. TNF- $\alpha$ also decreased KDR/flk-1 message levels in bovine aortic endothelial cells (data not shown), demonstrating that the effect of TNF- $\alpha$ was not species specific.

TNF- $\alpha$ decreased KDR/flk- 1 and flt- 1 mRNAs in a dosedependent fashion (Fig. 3). As little as $1 \mathrm{ng} / \mathrm{ml} \mathrm{TNF}-\alpha$ inhibited expression of the two mRNAs to nearly maximal levels in HUVEC. We conclude from the data presented in Figs. 2 and 3 that TNF- $\alpha$ specifically downregulated the mRNA for the VEGF receptors KDR/flk-1 and flt- 1 in a time- and dose-dependent fashion in human endothelial cells.

$T N F-\alpha$ decreases the rate of transcription but not the halflife of $K D R / f l k-1$. To determine whether TNF- $\alpha$ affected the steady-state level of KDR/flk-1 mRNA by increasing its rate of degradation, we measured KDR/flk-1 mRNA in the presence of actinomycin D $(5 \mu \mathrm{g} / \mathrm{ml})$ in HUVEC. The KDR/flk-1 mRNA half-life was $1.9 \mathrm{~h}$ in the absence of TNF- $\alpha$ and in-
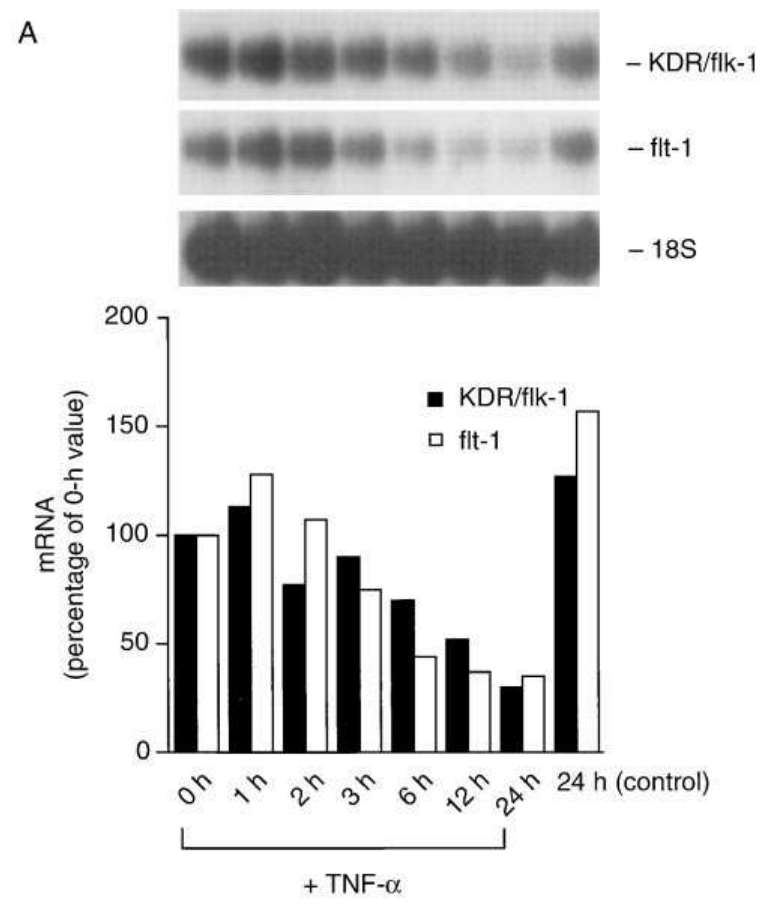

B

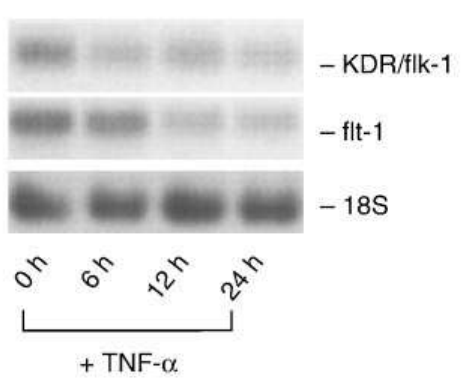

Figure 2. Time course of VEGF receptor mRNA downregulation by TNF- $\alpha$ in human endothelial cells. $(A)$ HUVEC were treated with TNF- $\alpha(10 \mathrm{ng} / \mathrm{ml})$, and total RNA was extracted from the cells at the indicated times. RNA was also extracted from control cells receiving vehicle but not TNF- $\alpha$. Northern blot analysis was performed with 10 $\mu \mathrm{g}$ of total RNA/lane. After electrophoresis the RNA was transferred to nitrocellulose filters, which were sequentially hybridized to ${ }^{32} \mathrm{P}-$-labeled human KDR/flk-1 and flt-1 probes. The filters were also hybridized with an $18 \mathrm{~S}$ probe to assess loading differences. The corrected density was plotted as a percentage of the 0 -h value. $(B)$ HAEC were treated with TNF- $\alpha(10 \mathrm{ng} / \mathrm{ml})$ for the indicated times, and RNA was harvested, blotted, and probed as above.

creased slightly to $2.6 \mathrm{~h}$ after treatment with $\mathrm{TNF}-\alpha(1 \mathrm{ng} / \mathrm{ml})$ for $12 \mathrm{~h}$ (Fig. 4), an insignificant difference. In similar experiments, TNF- $\alpha$ did not decrease the flt- 1 mRNA half-life (data not shown). Thus, the TNF- $\alpha$-induced decrease in the level of KDR/flk-1 and flt-1 mRNAs in HUVEC was not due to a decrease in the stability of the mRNA. Because this similarity in regulation between the two VEGF receptors argued for a common mechanism, we limited further characterization of regulation to KDR/flk-1.

We performed nuclear run-on experiments to determine the rate of $K D R / f l k-1$ gene transcription in the presence or absence of TNF- $\alpha$ and compared that to the rate of transcription of the constitutively expressed $\beta$-actin gene. In a representa- 

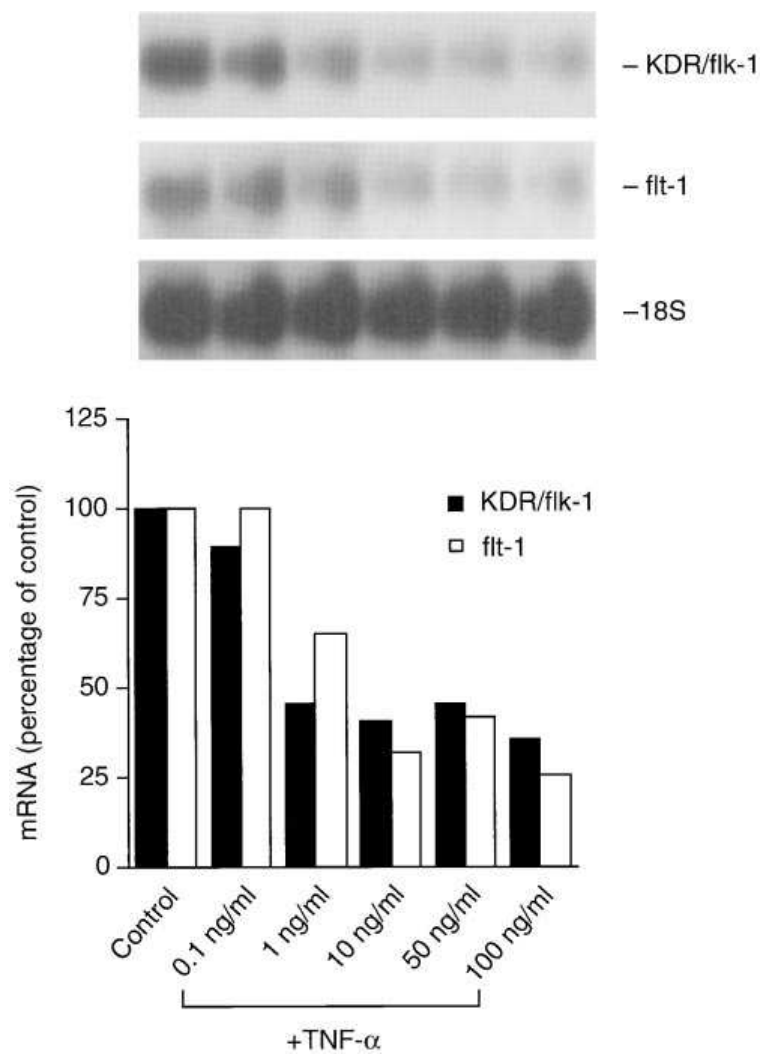

Figure 3. Dose response of VEGF receptor mRNA downregulation by TNF- $\alpha$ in human endothelial cells. HUVEC were incubated for $12 \mathrm{~h}$ with the indicated concentrations of TNF- $\alpha$, and total RNA was extracted from the cells at the end of each incubation. See Fig. $2 A$ for details.

tive experiment (of three), TNF- $\alpha$ ( $1 \mathrm{ng} / \mathrm{ml})$ decreased the rate of $K D R / f l k-1$ gene transcription (measured in PhosphorImager units) to $40 \%$ of base line but had no effect on the transcription of $\beta$-actin (Fig. 5). Thus, the TNF- $\alpha$-induced decrease in KDR/flk-1 mRNA was due to a decrease in the rate of transcription of the $K D R / f l k-1$ gene in HUVEC and not to a change in the stability of its mRNA.

Decrease in KDR/flk-1 mRNA by TNF- $\alpha$ depends on protein synthesis. To determine whether the decrease in KDR/ flk-1 mRNA required protein synthesis, we pretreated HUVEC with the protein synthesis inhibitor anisomycin at a concentration $(50 \mu \mathrm{M})$ five times higher than that which inhibited protein synthesis by $>95 \%$ (as measured by $\left[{ }^{3} \mathrm{H}\right]$ leucine uptake, data not shown). Anisomycin alone had little effect on KDR/ flk-1 expression at this dose (Fig. 6). However, pretreatment with anisomycin significantly blunted the effect of TNF- $\alpha$ on $\mathrm{KDR} / \mathrm{flk}-1$ expression in comparison with control (35 vs. $71 \%$ decrease, $P<0.05$ ), indicating that the effect of TNF- $\alpha$ on $\mathrm{KDR} / \mathrm{flk}-1$ in HUVEC was at least partly dependent on new protein synthesis. These results did not vary with the protein synthesis inhibitor used, as cycloheximide caused an identical inhibition of the TNF- $\alpha$ effect (data not shown).

Phorbol ester inhibits TNF- $\alpha$-induced downregulation of $K D R / f l k-1 m R N A$. To define further the signaling pathway(s) responsible for downregulation of KDR/flk-1 by TNF- $\alpha$, we treated HUVEC with agents that antagonize the effects of TNF- $\alpha$ on gene expression: TPA $(27,28)$, dexamethasone (29),

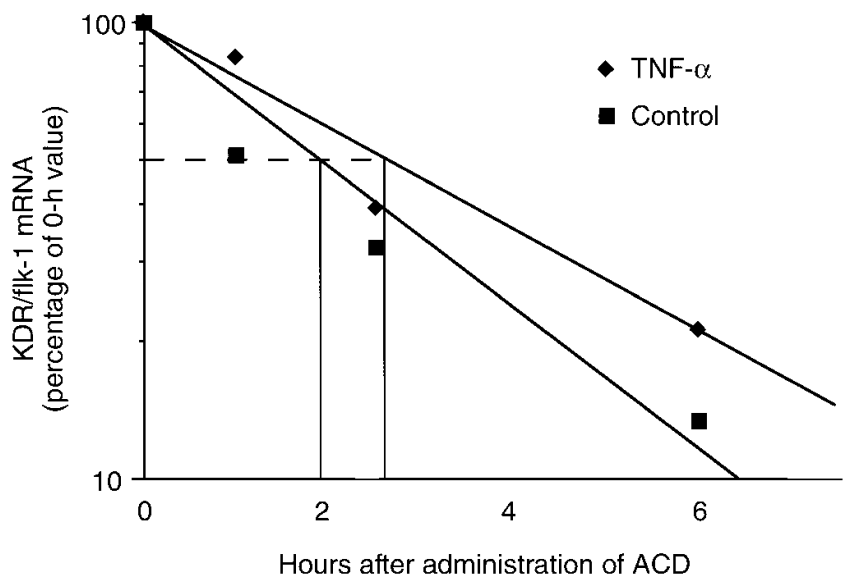

Figure 4. Effect of TNF- $\alpha$ on KDR/flk-1 mRNA half-life. HUVEC were exposed to vehicle (control, squares) or TNF- $\alpha(1 \mathrm{ng} / \mathrm{ml}$, diamonds) for $12 \mathrm{~h}$ before addition of actinomycin $\mathrm{D}(A C D, 5 \mu \mathrm{g} / \mathrm{ml})$. Total RNA was extracted from the cells at the indicated times after actinomycin D administration. Northern blot analyses were performed with $10 \mu \mathrm{g}$ of total RNA/lane. After transfer, the nitrocellulose filter was hybridized to ${ }^{32} \mathrm{P}$-labeled human KDR/flk-1 and $18 \mathrm{~S}$ probes. To correct for differences in loading, the signal density of each RNA sample hybridized to the KDR/flk-1 probe was divided by that hybridized to the $18 \mathrm{~S}$ probe. The corrected density was then plotted as a percentage of the 0 -h value (in log scale) against time. A representative of three independent experiments is shown.

indomethacin (30), dibutyryl-cyclic $\operatorname{AMP}(31,32), \operatorname{PDTC}(33)$, and TGF- $\beta 1$ (26). Dibutyryl-cyclic AMP, TGF- $\beta 1$, the antioxidant PDTC, dexamethasone (a glucocorticoid), and indomethacin (a prostaglandin synthase inhibitor) did not inhibit downregulation of KDR/flk-1 mRNA by TNF- $\alpha$ (Fig. 7). In contrast, phorbol ester treatment (TPA, $100 \mathrm{nM}$ ) for $24 \mathrm{~h}$

A

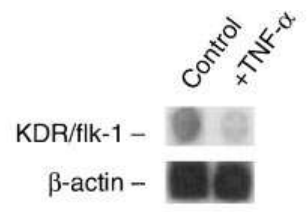

B

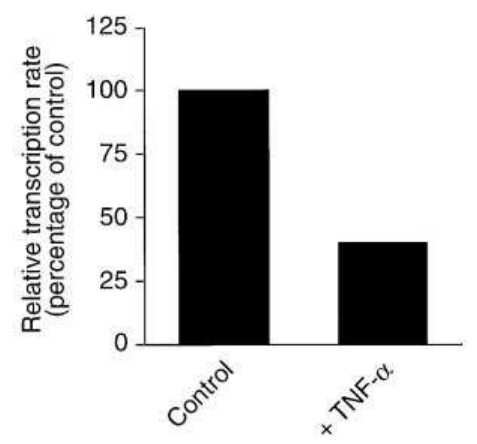

Figure 5. Effect of TNF- $\alpha$ on the transcriptional rate of $\mathrm{KDR} /$ flk-1. (A) Confluent HUVEC were treated with TNF- $\alpha(1 \mathrm{ng} / \mathrm{ml})$ or vehicle for $18 \mathrm{~h}$. Nuclei were isolated, and in vitro transcription was allowed to resume in the presence of $\left[\alpha-{ }^{32} \mathrm{P}\right]$ UTP. Equal amounts of ${ }^{32} \mathrm{P}$-labeled, in vitrotranscribed RNA probes from each group were hybridized to $1 \mu \mathrm{g}$ of denatured human KDR/flk-1 and $\beta$-actin cDNA that had been immobilized on nitrocellulose filters. $(B)$ To correct for differences in loading of the RNA probe, the signal density for KDR/flk-1 was divided by that for $\beta$-actin and is presented as a percentage of control. A representative of three experiments is shown. 
A

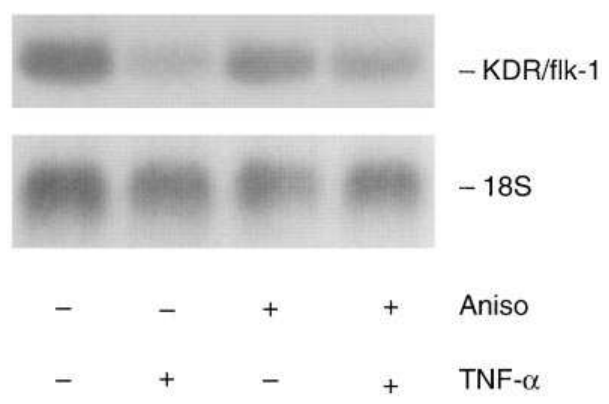

B

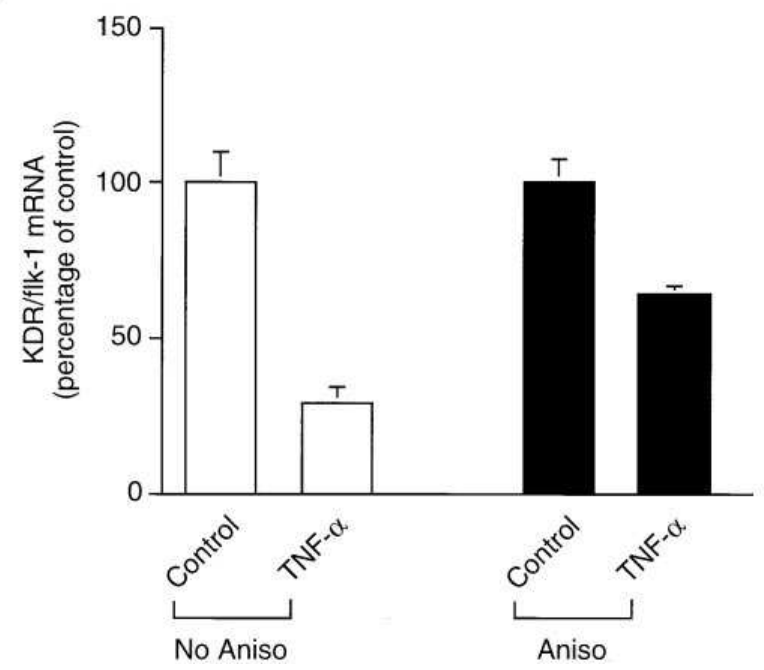

Figure 6. Effect of protein-synthesis inhibition on regulation of KDR/flk-1 by TNF- $\alpha$ in HUVEC. ( $A$ ) Confluent HUVEC were pretreated with vehicle or anisomycin $($ Aniso, $50 \mu \mathrm{M})$ for $45 \mathrm{~min}$ and then treated with vehicle or TNF- $\alpha(1 \mathrm{ng} / \mathrm{ml})$ for $12 \mathrm{~h}$, after which total RNA was extracted. See Fig. $2 A$ for details. $(B)$ The signal densities for KDR/flk-1 hybridization were corrected with those for $18 \mathrm{~S}$ hybridization and are presented as a percentage of control in each pretreatment group. Results represent the mean \pm SEM from three independent experiments.

moderately upregulated basal KDR/flk-1 mRNA expression and abolished the downregulation induced by TNF- $\alpha$ (Fig. 7).

$T N F-\alpha$ decreases new KDR/flk-1 protein synthesis. We precipitated ${ }^{35}$ S-labeled HUVEC lysates to demonstrate the production of immunoreactive KDR/flk-1 protein by HUVEC and to determine whether the decrease in KDR/flk-1 mRNA was accompanied by a decrease in protein synthesis. A rabbit anti-human KDR/flk-1 antibody (Santa Cruz sc-504) immunoprecipitated a single species with a molecular mass of approximately $205 \mathrm{kD}$ (Fig. 8), consistent with the size of full-length KDR/flk-1 protein when expressed in and immunoprecipitated from NIH 3 T3 or COS7 cells $(2,34)$. An identically sized species was detected by an antibody raised against a different KDR/flk-1 epitope (Santa Cruz sc-505) but not by a rabbit antibody raised similarly to the transcription factor Sp1 (data not shown), demonstrating the specificity of this interaction. After $24 \mathrm{~h}$ of TNF- $\alpha$ treatment, ${ }^{35}$ S-labeled KDR/flk-1 protein levels decreased to $18 \%$ of control (Fig. 8), confirming that the decrease in KDR/flk-1 mRNA induced by TNF- $\alpha$ was accompanied by a similar decrease in KDR/flk-1 protein expression.

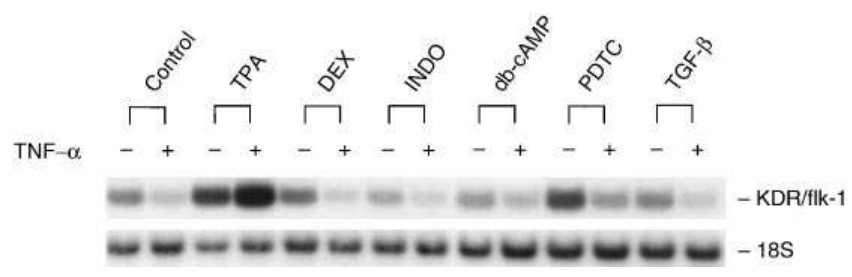

Figure 7. Effect of TPA pretreatment on KDR/flk-1 mRNA downregulated by TNF- $\alpha$. HUVEC were treated for $24 \mathrm{~h}$ with TPA (100 $\mathrm{nM})$ or for $1 \mathrm{~h}$ with dexamethasone $(D E X, 1 \mu \mathrm{M})$, indomethacin $(I N D O, 10 \mu \mathrm{M})$, dibutyryl-cyclic AMP $(d b-c A M P, 100 \mu \mathrm{M})$, PDTC $(100 \mu \mathrm{M})$, or TGF- $\beta 1(10 \mathrm{ng} / \mathrm{ml})$, and then treated with TNF- $\alpha(1 \mathrm{ng} /$ $\mathrm{ml}$ ) or vehicle for $18 \mathrm{~h}$. Total RNA was extracted from the cells at the end of each incubation. A representative of three experiments is shown. See Fig. $2 A$ for details.

\section{Discussion}

Despite the importance of angiogenesis in development and disease, the mitogenic, chemotactic, and morphogenetic mechanisms by which new vessels form are only beginning to be understood. Deletion of the $K D R / f l k-1$ gene by homologous recombination in mice abolishes vasculogenesis and endothelial cell formation, indicating that the VEGF system is essential for endothelial cells to differentiate from hemangioblastic precursors (35). Moreover, in addition to its involvement in angiogenesis and endothelial cell differentiation, VEGF prevents regression of newly formed vessels in vivo, which suggests that VEGF is an important endothelial cell survival factor (36). However, it remains unclear what other factors interact with VEGF to regulate angiogenesis and by what pathways these effects are exerted.

We examined the interaction between $\mathrm{TNF}_{-} \alpha$ and the VEGF/VEGF receptor system in human endothelial cells, and we show that TNF- $\alpha$ blocked DNA synthesis induced by VEGF (Fig. 1), as it blocked DNA synthesis induced by fibroblast growth factor (16). Further, we demonstrate that TNF- $\alpha$ directly interacted with the VEGF system by downregulating the VEGF receptors KDR/flk- 1 and flt- 1 in a dose- and timedependent fashion (Figs. 2 and 3). Because not much is known about the regulation of the VEGF receptors, we explored the mechanism by which TNF- $\alpha$ downregulated KDR/flk-1. We found that TNF- $\alpha$ decreased the rate of transcription of the $K D R / f l k-1$ gene but had little effect on its mRNA half-life (Figs. 4 and 5). Moreover, we show that new protein synthesis

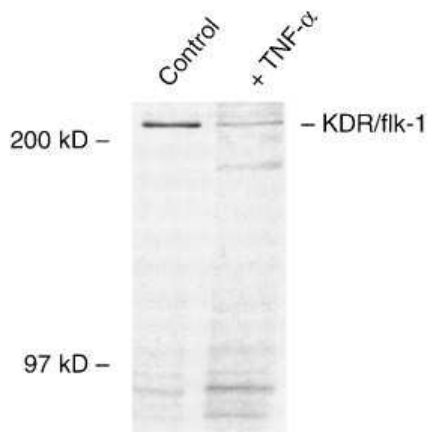

Figure 8. Inhibition of KDR/ flk-1 protein synthesis by TNF- $\alpha$. HUVEC were treated with TNF- $\alpha(1 \mathrm{ng} / \mathrm{ml})$ for $24 \mathrm{~h}$ and, after labeling with $\left[{ }^{35}\right.$ S $]$ methionine, lysates from these cells were incubated with a specific KDR/flk-1 antibody. Antigen-antibody complexes were immunoprecipitated with protein A Sepharose. Protein A conjugates were separated, washed, and denatured before fractionation on a 7\% SDS-polyacrylamide gel. Labeled proteins were identified by autoradiography. The experiment was repeated on three separate lysates. A representative gel is shown. 
was necessary for complete downregulation of KDR/flk-1 mRNA by TNF- $\alpha$ (Fig. 6). That inhibition of protein synthesis only partially attenuated KDR/flk-1 mRNA downregulation suggests that transcriptional regulation of this gene by $\mathrm{TNF}-\alpha$ may be mediated through a multiprotein complex, as is the case for TNF- $\alpha$-regulated vascular cell adhesion molecule-1 expression or transcription in endothelial cells $(37,38)$.

To delineate pathways responsible for the effect of TNF- $\alpha$ on transcription of the $K D R / f l k-1$ gene, we examined the effects of agents known to modulate transcriptional responses of TNF- $\alpha$ (Fig. 7). Of these agents, only TPA abolished downregulation of KDR/flk-1 mRNA expression by TNF- $\alpha$. Phorbol esters such as TPA have pleiomorphic effects on cell growth and gene expression (39). In contrast, neither dexamethasone, a glucocorticoid with multiple effects including inhibition of AP-1 and NFKB activation by TNF- $\alpha(40,41)$, nor PDTC, an antioxidant and suppressor of $\mathrm{NF \kappa B}$ activity in endothelial cells after TNF- $\alpha$ stimulation (33), prevented TNF- $\alpha$-induced downregulation of KDR/flk-1 mRNA. This contrast (Fig. 7) would indicate that the effect of $\mathrm{TNF}-\alpha$ on $K D R / f l k-1$ gene regulation is independent of intracellular signaling pathways blocked by PDTC or dexamethasone and is mediated by pathways sensitive to phorbol ester.

TNF- $\alpha$ increases expression of a variety of genes (14), as would befit a central mediator of the inflammatory process, and AP-1 and NFKB complexes are by far the most commonly identified trans-acting factors that mediate this process (4244). Although the transcriptional downregulation by $\mathrm{TNF}_{-} \alpha$ of $K D R / f l k-1$ gene expression is rare (Fig. 7), it is not without precedent. TNF- $\alpha$ downregulates transcription of thrombomodulin in endothelial cells by an undefined mechanism (45), and TNF- $\alpha$ inhibits vitamin D-induced transcription of the rat osteocalcin gene in osteoblastic cells through interactions that do not involve AP-1 or NFkB binding sites $(46,47)$. TNF- $\alpha$ also induces binding of an inhibitory protein complex to cisacting elements in the $\alpha 2(I)$ collagen gene in human fibroblasts (48). This protein complex has not been identified; however, it does not include immunoreactive AP-1 or NFkB members.

In light of the foregoing observations, our finding that AP-1 and NFkB activities are not likely to mediate the regulatory effects of TNF- $\alpha$ on KDR/flk-1 mRNA expression suggests that novel trans-acting factors mediate the inhibitory effects of $\mathrm{TNF}-\alpha$ on expression of genes such as those encoding $\alpha 2(\mathrm{I})$ collagen, osteocalcin, and the VEGF receptors. To search for these factors, we have examined the effect of TNF- $\alpha$ on reporter gene expression under control of $4 \mathrm{~kb}$ of $5^{\prime}$ flanking sequence of the $K D R / f l k-1$ gene (which contains two consensus NFkB binding sites [25]) in transient transfection assays of bovine aortic endothelial cells (data not shown). Because we have not discovered TNF- $\alpha$-responsive cis-acting elements within this $5^{\prime}$ flanking sequence, we speculate that TNF- $\alpha$ exerts its transcriptional effects on $K D R / f l k-1$ through DNA elements outside the cloned $5^{\prime}$ flanking sequence.

As a central regulator of the local inflammatory response, TNF- $\alpha$ modulates the expression of many genes in endothelial cells. In particular, TNF- $\alpha$ induces the expression of genes involved in cytoadhesion, thrombosis, and the inflammatory response, processes referred to collectively as endothelial activation (49). Our results demonstrate that in addition to the transient induction by TNF- $\alpha$ of adhesion molecules and procoagulant factors, TNF- $\alpha$ also induces a dramatic and sustained reduction in VEGF receptor expression as part of the activation program. Although inhibition of endothelial cell growth and survival may serve as a brake on the inflammatory response during the early stages of endothelial activation, this growth inhibition may contribute to pathophysiologic responses in the later stages of cytokine-mediated diseases. For example, in septic shock, neutrophil- and lymphocyte-mediated endothelial cell injury and loss of monolayer integrity may go unrepaired, which in turn would accelerate vascular leakage and increase leukocyte adhesion to the endothelial surface long after the initial infectious insult had subsided $(50,51)$.

Our data indicate that TNF- $\alpha$ may exert its antiangiogenic effects at least partly by decreasing synthesis of VEGF receptors. The recent discovery that TNF- $\alpha$ and VEGF induce angiogenesis through two distinct $\alpha_{\mathrm{V}}$ integrin-mediated pathways is therefore of particular interest (52). Our findings raise the possibility that a factor from one such pathway with bifunctional angiogenic activity (TNF- $\alpha$ ) may actually inhibit the effects of VEGF in vivo by acting through the other pathway. It is therefore tempting to speculate that the two $\alpha_{\mathrm{V}}$ integrinmediated pathways subserve angiogenesis in divergent physiologic roles (for example, inflammatory versus developmental). Clearly, a complete elucidation of the interaction between angiogenic factors such as TNF- $\alpha$ and VEGF will be necessary before these pathways and the physiologic processes they mediate are fully understood.

\section{Acknowledgments}

We extend our gratitude to Mary Mitchell for her enthusiasm and support of our work. We thank Thomas McVarish for editorial assistance and Bonna Ith for technical assistance.

This work was supported in part by National Institutes of Health grants F32-GM16771-02 (C. Patterson), RO1-GM53249 (M.-E. Lee), and KO8-HL03194 (M.A. Perrella) and by a grant from the BristolMyers Squibb Pharmaceutical Research Institute.

\section{References}

1. Folkman, J. 1995. Angiogenesis in cancer, vascular, rheumatoid and other disease. Nat. Med. 1:27-31.

2. Millauer, B., L.K. Shawver, K.H. Plate, W. Risau, and A. Ullrich. 1994. Glioblastoma growth inhibited in vivo by a dominant-negative Flk-1 mutant. Nature (Lond.). 367:576-579.

3. Aiello, L., E. Pierce, E. Foley, H. Takagi, H. Chen, L. Riddle, N. Ferrara, G. King, and L. Smith. 1995. Suppression of retinal neovascularization in vivo by inhibition of vascular endothelial growth factor using soluble VEGF-receptor chimeric proteins. Proc. Natl. Acad. Sci. USA. 92:10457-10461.

4. Isner, J., K. Walsh, J. Symes, A. Pieczek, S. Takeshita, J. Lowry, S. Rossow, K. Rosenfield, L. Weir, E. Brogi, and R. Schainfeld. 1995. Arterial gene therapy for therapeutic angiogenesis in patients with peripheral artery disease. Circulation. 91:2687-2692.

5. Klagsbrun, M., and P.A. D'Amore. 1991. Regulators of angiogenesis. Ann. Rev. Physiol. 53:217-239.

6. Klagsbrun, M., and S. Soker. 1993. VEGF/VPF: the angiogenesis factor found? Curr. Biol. 3:699-702.

7. Leung, D.W., G. Cachianes, W.-J. Kuang, D.V. Goeddel, and N. Ferrarra. 1989. Vascular endothelial growth factor is a secreted angiogenic mitogen. Science (Wash. DC). 246:1306-1309.

8. Connolly, D.T., D.M. Heuvelman, R. Nelson, J.V. Olander, B.L. Eppley, J.J. Delfino, R.M. Leingruber, and J. Feder. 1989. Tumor vascular permeability factor stimulates endothelial cell growth and angiogenesis. J. Clin. Invest. 84: 1470-1478.

9. Aiello, L.P., R.L. Avery, P.G. Arrigg, B.A. Keyt, H.D. Jampel, S.T. Shah, L.R. Pasquale, H. Thieme, M.A. Iwamoto, J.E. Park, H.V. Nguyen, L.M. Aiello, N. Ferrara, and G.L. King. 1994. Vascular endothelial growth factor in ocular fluid of patients with diabetic retinopathy and other retinal disorders. $N$. Engl. J. Med. 331:1480-1487.

10. Berkman, R., M. Merrill, and W. Reinhold. 1993. Expression of the vascular permeability/vascular endothelial growth factor gene in central nervous system neoplasms. J. Clin. Invest. 91:153-159.

11. Shweiki, D., A. Itin, D. Soffer, and E. Keshet. 1992. Vascular endothe- 
lial growth factor induced by hypoxia may mediate hypoxia-initiated angiogenesis. Nature (Lond.). 359:843-845.

12. Jakeman, L.B., M. Armanini, H.S. Phillips, and N. Ferrara. 1993. Developmental expression of binding sites and messenger ribonucleic acid for vascular endothelial growth factor suggests a role for this protein in vasculogenesis and angiogenesis. Endocrinology. 133:848-859.

13. Breier, G., U. Albrecht, S. Sterrer, and W. Risau. 1992. Expression of vascular endothelial growth factor during embryonic angiogenesis and endothelial cell differentiation. Development. 114:521-532.

14. Vilcek, J., and T. Lee. 1991. Tumor necrosis factor. J. Biol. Chem. 266: 7313-7316.

15. Sunderkotter, C., M. Goebeler, K. Schulze-Osthoff, R. Bhardwaj, and C. Sorg. 1991. Macrophage-derived angiogenesis factors. Pharmac. Ther. 51: $195-216$.

16. Frater-Schroder, M., W. Risau, R. Hallmann, and P. Gautsch. 1987. Tumor necrosis factor type $\alpha$, a potent inhibitor of endothelial cell growth in vitro, is angiogenic in vivo. Proc. Natl. Acad. Sci. USA. 84:5277-5281.

17. Leibovich, S., P. Polverini, H. Shepard, D. Wiseman, V. Shively, and N. Nuseir. 1987. Macrophage-induced angiogenesis is mediated by tumour necrosis factor- $\alpha$. Nature (Lond.). 329:630-632.

18. Pandey, A., H. Shao, R. Marks, P. Polverini, and V. Dixit. 1995. Role of $\mathrm{B} 61$, the ligand for the Eck receptor tyrosine kinase, in TNF- $\alpha$-induced angiogenesis. Science (Wash. DC). 268:567-569.

19. Stolpen, A., E. Guinan, W. Fiers, and J. Pober. 1986. Recombinant tumor necrosis factor and immune interferon act singly and in combination to reorganize human vascular endothelial cell monolayers. Am. J. Path. 123:16-24.

20. Sato, N., T. Goto, K. Haranaka, N. Satomi, H. Nariuchi, Y. ManoHirano, and Y. Sawasaki. 1986. Actions of tumor necrosis factor on cultured vascular endothelial cells. J. Natl. Cancer Inst. 76:1113-1121.

21. Burke-Gaffney, A., and A. Keenan. 1993. Does TNF- $\alpha$ directly increase endothelial cell monolayer permeability? Agents Actions. 38:83-85.

22. Sambrook, J., E.F. Fritsch, and T. Maniatis. 1989. Molecular Cloning: A Laboratory Manual. Cold Spring Harbor Laboratory Press, Cold Spring Harbor, N.Y.

23. Li, J., M.A. Perrella, J.-C. Tsai, S.-F. Yet, C.-M. Hsieh, M. Yoshizumi, C. Patterson, W.O. Endege, F. Zhou, and M.-E. Lee. 1995. Induction of vascular endothelial growth factor gene expression by interleukin- $1 \beta$ in rat aortic smooth muscle cells. J. Biol. Chem. 270:308-312.

24. Yoshizumi, M., S. Kourembanas, D.H. Temizer, R.P. Cambria, T. Quertermous, and M.E. Lee. 1992. Tumor necrosis factor increases transcription of the heparin-binding epidermal growth factor-like growth factor gene in vascular endothelial cells. J. Biol. Chem. 267:9467-9469.

25. Patterson, C., M.A. Perrella, C.-M. Hsieh, M. Yoshizumi, M.-E. Lee, and E. Haber. 1995. Cloning and functional analysis of the promoter for KDR/ flk-1, a receptor for vascular endothelial growth factor. J. Biol. Chem. 270: 23111-23118.

26. Perrella, M.A., M. Yoshizumi, Z. Fen, J.-C. Tsai, C.-M. Hsieh, S. Kourembanas, and M.-E. Lee. 1994. Transforming growth factor- $\beta 1$, but not dexamethasone, down-regulates nitric-oxide synthase mRNA after its induction by interleukin-1 $\beta$ in rat smooth muscle cells. J. Biol. Chem. 269:1459514600 .

27. Matsubara, N., S. Fuchimoto, and K. Orita. 1991. Tumour necrosis factor-alpha induces translocation of protein kinase $\mathrm{C}$ in tumour necrosis factorsensitive cell lines. Immunology. 73:457-459.

28. Sanguedolce, M., C. Capo, P. Bongrand, and J. Mege. 1992. Zymosanstimulated tumor necrosis factor-alpha production by human monocytes. Down-modulation by phorbol ester. J. Immunol. 148:2229-2236.

29. van de Stolpe, A., E. Caldenhoven, B. Stade, L. Koenderman, J. Raaijmakers, J. Johnson, and P. van der Saag. 1994. 12-O-tetradecanoylphorbol13-acetate- and tumor necrosis factor alpha-mediated induction of intercellular adhesion molecule- 1 is inhibited by dexamethasone: functional analysis of the human intercellular adhesion molecule-1 promoter. J. Biol. Chem. 269:61856192.

30. Diaz, A., E. Munoz, R. Johnston, J. Korn, and S. Jimenez. 1993. Regulation of human lung fibroblast alpha 1(I) procollagen gene expression by tumor necrosis factor alpha, interleukin-1 beta, and prostaglandin E2. J. Biol. Chem. 268:10364-10371.

31. Koga, S., S. Morris, S. Ogawa, H. Liao, J. Bilezikian, G. Chen, W. Thompson, T. Ashikaga, J. Brett, D. Stern, and D. Pinsky. 1995. TNF modulates endothelial properties by decreasing CAMP. Am. J. Physiol. 268:C1104C1113.
32. De Luca, L., D. Johnson, M. Whitley, T. Collins, and J. Pober. 1994. cAMP and tumor necrosis factor competitively regulate transcriptional activation through and nuclear factor binding to the cAMP-responsive element/activating transcription factor element of the endothelial leukocyte adhesion molecule-1 (E-selectin) promoter. J. Biol. Chem. 269:19193-19196.

33. Marui, N., M.K. Offermann, R. Swerlick, C. Kunsch, C.A. Rosen, M. Ahmad, R.W. Alexander, and R.M. Medford. 1993. Vascular cell adhesion molecule-1 (VCAM-1) gene transcription and expression are regulated through an antioxidant-sensitive mechanism in human vascular endothelial cells. J. Clin. Invest. 92:1866-1874.

34. Quinn, T.P., K.G. Peters, C. De Vries, N. Ferrara, and L.T. Williams 1993. Fetal liver kinase 1 is a receptor for vascular endothelial growth factor and is selectively expressed in vascular endothelium. Proc. Natl. Acad. Sci. USA. 90:7533-7537.

35. Shalaby, F., J. Rossant, T. Yamaguchi, M. Gertsenstein, X.-F. Wu, M. Breitman, and A. Schuh. 1995. Failure of blood-island formation and vasculogenesis in Flk-1-deficient mice. Nature (Lond.). 376:62-66.

36. Alon, T., I. Hemo, A. Itin, J. Peer, J. Stone, and E. Keshet. 1995. Vascular endothelial growth factor acts as a survival factor for newly formed retinal vessels and has implications for retinopathy of prematurity. Nature Med. 1: 1024-1028.

37. Neish, A., L. Khachigian, A. Park, V. Baichwal, and T. Collins. 1995. $\mathrm{Sp} 1$ is a component of the cytokine-inducible enhancer in the promoter of vascular cell adhesion molecule-1. J. Biol. Chem. 270:28903-28909.

38. Neish, A., M. Read, D. Thanos, R. Pine, T. Maniatis, and T. Collins. 1995. Endothelial IRF-1 cooperates with NF-кB as a transcriptional activator of vascular cell adhesion molecule-1. Mol. Cell. Biol. 15:2558-2569.

39. Kikkawa, U., A. Kishimoto, and Y. Nishizuka. 1989. The protein kinase C family: Heterogeneity and its implications. Ann. Rev. Biochem. 58:31-44.

40. Konig, H., H. Ponta, H. Rahmsdorf, and P. Herrlich. 1992. Interference between pathway-specific transcription factors: glucocorticoids antagonize phorbol ester-induced AP-1 activity without altering AP-1 site occupation in vivo. EMBO (Eur. Mol. Biol. Organ.) J. 11:2241-2246.

41. Scheinman, R., P. Cogswell, A. Lofquist, and A. Baldwin. 1995. Role of transcriptional activation of I kappa B alpha in mediation of immunosuppression by glucocorticoids. Science (Wash. DC). 270:283-286.

42. Read, M., M. Whitley, A. Williams, and T. Collins. 1994. NFkB and IкB- $\alpha$ : An inducible regulatory system in endothelial activation. J. Exp. Med. 179:503-512.

43. Sancéau, J., T. Kaisho, T. Hirano, and J. Wietzerbin. 1995. Triggering of the human interleukin- 6 gene by interferon- $\gamma$ and tumor necrosis factor- $\alpha$ in monocytic cells involves cooperation between interferon regulatory factor-1, NFкB, and Sp1 transcription factors. J. Biol. Chem. 270:27920-27931.

44. Brenner, D.A., M. O'Hara, P. Angel, M. Chojkier, and M. Karin. 1989. Prolonged activation of jun and collagenase genes by tumour necrosis factoralpha. Nature (Lond.). 337:661-663.

45. Conway, E., and R. Rosenberg. 1988. Tumor necrosis factor suppresses transcription of the thrombomodulin gene in endothelial cells. Mol. Cell. Biol. 8:5588-5592.

46. Kuno, H., S. Kurian, G. Hendy, J. White, H. DeLuca, C.-O. Evans, and M. Nanes. 1994. Inhibition of 1,25-dihydroxy vitamin D3 stimulated osteocalcin gene transcription by tumor necrosis factor- $\alpha$ : structural determinants within the vitamin D response element. Endocrinology. 134:2524-2532.

47. Nanes, M., H. Kuno, M. Demay, M. Kurian, G. Hendy, H. DeLuca, L. Titus, and J. Rubin. 1994. A single up-stream element confers responsiveness to 1,25-dihydroxyvitamin D3 and tumor necrosis factor- $\alpha$ in the rat osteocalcin gene. Endocrinology. 134:1113-1120.

48. Inagaki, Y., S. Truter, S. Tanaka, M. Di Liberto, and F. Ramirez. 1995. Overlapping pathways mediate the opposing actions of tumor necrosis factor- $\alpha$ and transforming growth factor- $\beta$ on $\alpha 2(\mathrm{I})$ collagen gene transcription. J. Biol. Chem. 270:3353-3358.

49. Pober, J.S., and R.S. Cotran. 1990. The role of endothelial cells in inflammation. Transplantation. 50:537-544.

50. Brigham, K., and B. Meyrick. 1986. Endotoxin and lung injury. Am. Rev. Resp. Dis. 133:913-920.

51. Young, J.-E., C.-C. Liu, P.-M. Persechini, and Z. Cohn. 1988. Perforindependent and -independent pathways of cytotoxicity mediated by lymphocytes. Immunol. Rev. 103:161-180.

52. Friedlander, M., P.C. Brooks, R.W. Shaffer, C.M. Kincaid, J.A. Varner, and D. Cheresh. 1995. Definition of two angiogenic pathways by distinct $\alpha_{V}$ integrins. Science (Wash. DC). 270:1500-1502. 